\title{
Impact of Bolsa Familia Program on the nutritional status of children and adolescents from two Brazilian regions
}

\author{
Impacto do Programa Bolsa Família no \\ estado nutricional de crianças e adolescentes \\ de duas regiões brasileiras
}

Naiara SPERANDIO ${ }^{1}$

Cristiana Tristão RODRIGUES²

Sylvia do Carmo Castro FRANCESCHINI ${ }^{3}$

Silvia Eloiza PRIORE ${ }^{3}$

A B S T R A C T

\section{Objective}

To assess and compare the impact of the Bolsa Familia Program (Family Allowance) on the nutritional status of children and adolescents from the Brazilian Northeastern and Southeastern regions.

\section{Methods}

The study used data from a database derived from a subsample of the Family Budget Survey conducted from 2008 to 2009. The ratios of underweight, stunted, and overweight children were calculated. Impact measurement analysis was preceded by propensity score matching, which matches beneficiary and non-beneficiary families in relation to a set of socioeconomic features. The nearest-neighbor matching algorithm estimated the program impact.

\section{Results}

The ratio of underweight children and adolescents was, on average, $1.1 \%$ smaller in the beneficiary families than in the non-beneficiary families in the Northeastern region. As for the Southeastern region, the ratio of overweight children and adolescents was, on average, $4.2 \%$ smaller in the beneficiary families. The program did not affect stunting in either region.

\footnotetext{
1 Universidade Federal do Rio de Janeiro, Curso de Nutrição. R. Professor Aloisio Teixeira Gomes da Silva, 50, Granja dos Cavaleiros, 27930-560, Macaé, RJ, Brasil. Correspondência para/Correspondence to: N SPERANDIO. E-mail: <naiarasperandio@ macae.ufrj.br>.

2 Universidade Federal de Viçosa, Centro de Ciências Exatas e Tecnológocas, Departamento de Economia. Viçosa, MG, Brasil.

3 Universidade Federal de Viçosa, Centro de Ciências Biológicas e da Saúde, Departamento de Nutrição. Viçosa, MG, Brasil.
} 


\section{Conclusion}

The results showed the positive impact and good focus of the program. Thus, once linked to structural actions, the program may help to improve the nutritional status and quality of life of its beneficiaries.

Keywords: Malnutrition. Nutritional status. Overweight. Public policy.

\section{RE S U M O}

\section{Objetivo}

Avaliar e comparar o impacto do Programa Bolsa Família no estado nutricional de crianças e adolescentes do Nordeste e Sudeste brasileiro.

\section{Métodos}

A base de dados procedeu de uma subamostra da Pesquisa de Orçamento Familiar de 2008-2009. Calculou-se a proporção de crianças e adolescentes com baixo peso, baixa estatura e excesso de peso. A análise da medida de impacto foi precedida de técnica (Propensity Score Matching) que assemelha, familias beneficiárias e não beneficiárias, em relação a um conjunto de características socioeconômicas. O impacto do programa foi estimado através do algoritmo de pareamento do vizinho mais próximo.

\section{Resultados}

No Nordeste, a proporção de crianças e adolescentes abaixo do peso foi em média, 1,1\% menor nas famílias beneficiárias, em comparação às não beneficiárias. No Sudeste, a proporção de crianças e adolescentes acima do peso foi em média, 4,2\% menor nas famílias beneficiárias. Não foi observado impacto do programa sobre $o$ déficit de estatura em ambas as regiões.

\section{Conclusão}

Os resultados retrataram impacto positivo e boa focalização do programa, que se atrelado a ações estruturais pode contribuir para melhoria do estado nutricional e qualidade de vida dos beneficiários.

Palavras-chave: Desnutrição. Estado nutricional. Sobrepeso. Política social.

\section{NTRODUCTION}

In the last 34 years, the secular nutritional status change of Brazilian children and adolescents reflects a decline of malnutrition and an increase of excess weight in this population [1].

The increase in maternal education level, family purchasing power, and access to health care and basic sanitation stand out as the main factors responsible for the decline of malnutrition in Brazil $[2,3]$. One of the determining factors for the higher purchasing power of the Brazilian population, especially since 2003, was the expansion of the cash transfer programs, especially the Bolsa Familia Program (PBF, Family Allowance Program) [4,5].

The Bolsa Familia Program was created by Interin Measure $n^{\circ} 132$ in October 2003 and regulated by Decree $n^{\circ} 5,209$ of 2004 . The target population are families in poverty (with a per capita family income per month of $R \$ 77.01$ to $R \$ 154.00$, as long as these families include children, adolescents, pregnant women, and breastfeeding women) and extreme poverty (with a per capita family income per month below R\$77.00) [6].

The operationalization of the program occurs via cash transfer and compliance with a number of requirements in the areas of health, education, and social assistance $[6,7]$.

The requirements are mutual compromises assumed by the government and families. Children and adolescents aged 6 to 15 years must have at least $85 \%$ school attendance, and those aged 16 to 17 years, at least $75 \%$ school attendance. The guardians of children aged less than seven years must follow the vaccination 
schedule and the child growth and development monitoring conducted by the Family Health Strategy units $[6,7]$.

Currently, the program benefits approximately 14 million families in poverty or extreme poverty, most of them from the Northeast region. This region stands out in Brazil because it has the highest prevalence of extreme poverty $(10.5 \%)$ of all Brazilian regions [6].

The distribution of anthropometric indicators in Brazilian regions repeats the trend observed in Brazil: reduction of malnutrition and increase of excess weight in all age groups. However, according to the last Pesquisa de Orçamento Familiar (POF, Family Budget Survey), the Northeast region stood out because it had the highest prevalence of underweight, and the Southeast region, because it had the highest prevalence of excess weight [1].

Studies that compared these two regions (Southeast and Northeast) before POF, especially the Pesquisa sobre Padrões de Vida (PPV, Life Standard Survey), found similar results, that is, higher prevalences of overweight and obesity in the Southeast region and higher prevalence of malnutrition in the Northeast $[8,9]$.

According to the results of the Pesquisa Nacional de Amostra por Domicilios (PNAD, National Household Sampling Survey), 38.1\% of the households in the Northeast are food insecure, which was the highest prevalence found by the survey in Brazil, while in the Southeast this proportion affected less than one-fourth of the households (14.5\%) [10].

The Northeast and Southeast regions include two-thirds of the Brazilian population and represent the extreme unequal development in Brazil. This fact led the Instituto Brasileiro de Geografia e Estatística (IBGE, Brazilian Institute of Geography and Statistics) to select these two regions, and not the other regions, to conduct the PPV [8].

Different social and economic contexts may influence the results of public policies, especially the PBF, which uses the same criteria throughout the country to determine families' eligibility for the program and calculate the amount of money they will receive.

Given the above, the present study aimed to assess and compare the impact of the $\mathrm{PBF}$ on the nutritional status of children and adolescents from beneficiary families in the Brazilian Northeast and Southeast regions.

\section{METHODS}

The present study used the database of POF conducted by the IBGE from May 19, 2008 to May 18, 2009. This survey covered 4,696 census tracts, which corresponded to 55,970 households and 190,159 individuals [1].

Pesquisa de Orçamento Familiar performed two-stage cluster sampling. The first stage consisted of the geographic and economic stratification of the census tracts (primary sampling unit), of IBGE's Amostra Mestra de Inquéritos Domiciliares (Master Sample of Household Surveys). The Master Sample tracts were selected by probabilistic sampling proportional to the number of households in the sector [1].

The second stage consisted of selecting permanent private households, selected by simple random sampling without reposition inside each tract. The tracts were distributed along 12 months to ensure representativeness during the year's four quarters [1]

The present study chose to assess information regarding the nutritional status of children and adolescents, which constitute the target population of the PBF. Given the inaccuracy of measuring the height of children aged less than 5 years by the 2008/2009 POF, the present study used data of children aged more than five years. Adolescents were defined as individuals aged 10 to 19 years [1].

\section{Nutritional status assessment}

The weight and height of all household dwellers were measured at the household during 
POF's data collection. A portable electronic scale with capacity of $150 \mathrm{~kg}$ and accuracy of $100 \mathrm{~g}$ measured weight. Height (height measurement for individuals aged more than 24 months) was measured by portable stadiometers with a telescopic tape measure $200 \mathrm{~cm}$ in length and $0.1 \mathrm{~cm}$ graduation [1].

Weight and height were used for calculating the following anthropometric indices: Height-for-Age (H/A) and Body Mass Index (BMI)-for-Age (BMI/A) in Z-scores. Nutritional status was classified according to Z-score, using as anthropometric reference the growth curves provided by the World Health Organization (WHO) in 2007 [11]. The data were assessed by the software AntroPlus 2007 (World Health Organization, Geneva, Switzerland).

All children and adolescents with BMI/A and H/A Z-scores below -2 were classified as underweight and stunted, respectively. Children with BMI/A Z-score above +1 were classified as having excess weight. Values considered biologically implausible (six standard deviations higher than the reference distribution for height and five standard deviations higher than the reference distribution for BMI) were excluded [12].

After individual classification, that is, classification of each child and adolescent in the family, we estimated the proportion of children and adolescents in beneficiary and nonbeneficiary families with underweight, stunting, and excess weight.

\section{Estimating the impact of Bolsa Familia Program}

Since families were not randomly distributed into a beneficiary (intervention) group and a nonbeneficiary (control) group, they were matched for some socioeconomic characteristics (potential confounders) before comparison. The procedure used was the propensity score matching [1], henceforth called propensity score.
The propensity score was estimated by a probit regression model. In this regression analysis, the dependent variable was a dummy given a value of one to represent families who received the $\mathrm{PBF}$, and zero to represent families who did not receive the aid. The explanatory variables used in the model: mean per capita income; number of household dwellers; number of sons and daughters; number of children and adolescents; number of bathrooms; household connection to the electric grid and sewerage; garbage collection; type of construction (wood/masonry); household location; and sex, education level, and skin color of the family head.

After calculating the propensity score, cases (families) with similar scores and socioeconomic characteristics were identified. The families who received or not the benefit were matched into blocks. The matched blocks were compared with respect to score similarity by a process called balancing (balancing hypothesis). The blocks that did not satisfy the balancing criterion, that is, those whose variables used for calculating the score differed significantly, were automatically excluded from the sample. Only the matched blocks of beneficiary and non-beneficiary families with similar propensity scores remained in the impact measurement analysis.

After the final number of beneficiary and non-beneficiary families who met the balancing criterion was determined, we calculated the Average Treatment effect on the Treated (ATT) using the nearest-neighbor matching technique [13]. This process matched every family in the treatment group with the family in the control group with the nearest propensity score. ATT was determined to assess the impact of the PBF on the proportion of underweight, stunted, and overweight/obese children and adolescents.

In order to characterize the beneficiary and non-beneficiary families of the two Brazilian regions, the mean and percentage values of the demographic and socioeconomic variables 
were estimated. Fisher's exact test compared the proportions, and the Student's $t$-test compared the means.

In order to rectify the importance of using propensity score matching for assessing the impact of public policies, the proportions of underweight, stunted, and overweight/obese children and adolescents were compared before and after the families were matched for score.

The software Stata (Stata Corp., College Station, Texas, United States) ('pscore ado' resource) calculated the propensity score, identified the families with similar propensity scores, balanced the block pairs, and calculated the ATT taking into consideration the complex design of the sample. The significance level was set at $5 \%$ for all statistical tests.

This study was approved by the Human Research Ethics Committee of the Universidade FederaldeViçosa (CAE:21927913.9.0000.5153).

\section{RES U L T S}

In the Northeast region, 6,718 families had children and adolescents aged 5 to 19 years; of these, $33.0 \%(N=2,216)$ were beneficiaries of the PBF. In the Southeast region, there were 1,670 such families, and $22.7 \%(n=379)$ were beneficiaries.

In both regions PBF beneficiary families had smaller per capita monthly income, family heads with lower education level, smaller access to public services like garbage collection and sewerage connection, and higher number of children and adolescents than non-beneficiary families (Table 1).

In addition to the abovementioned variables, the beneficiary families in the Northeast region were larger, and the number of rooms and bathrooms in the household was smaller. In the Southeast region, more beneficiary families were headed by women (Table 1).

Table 1. Socioeconomic and demographic characteristics of the beneficiary and non-beneficiary families of the Bolsa Familia Program.

\begin{tabular}{|c|c|c|c|c|c|c|}
\hline \multirow{3}{*}{ Variables } & \multicolumn{6}{|c|}{ Bolsa Família Program } \\
\hline & \multicolumn{3}{|c|}{ Northeast } & \multicolumn{3}{|c|}{ Southeast } \\
\hline & Yes & No & $p$ & Yes & No & $p$ \\
\hline Per capita monthly income & 129.0 & 178.2 & $<0.01^{\mathrm{a}}$ & 166.0 & 201.3 & $<0.01^{\mathrm{a}}$ \\
\hline Household head education level (years of schooling) & 3.2 & 4.0 & $0.01^{\mathrm{a}}$ & 4.5 & 5.2 & $<0.01^{\mathrm{a}}$ \\
\hline$\%$ female household head & 30.7 & 30.1 & $0.12^{b}$ & 37.7 & 31.5 & $<0.01^{b}$ \\
\hline$\%$ white & 22.9 & 23.9 & $0.37^{\mathbf{b}}$ & 39.8 & 38.0 & $0.12^{\mathrm{b}}$ \\
\hline$\%$ black & 6.5 & 7.6 & $0.10^{\mathbf{b}}$ & 9.2 & 8.8 & $0.81^{b}$ \\
\hline$\%$ brown & 69.8 & 67.6 & $0.07^{\mathbf{b}}$ & 50.4 & 49.3 & $0.33^{\mathbf{b}}$ \\
\hline Number of household dwellers & 4.9 & 4.7 & $<0.01^{\mathrm{a}}$ & 4.7 & 4.5 & $0.31^{\mathrm{a}}$ \\
\hline Number of sons and daughters & 2.2 & 2.5 & $0.06^{\mathrm{a}}$ & 2.7 & 2.3 & $<0.01^{\mathrm{a}}$ \\
\hline Number of children and adolescents & 2.3 & 2.0 & $<0.01^{\mathrm{a}}$ & 2.6 & 2.2 & $<0.01^{\mathrm{a}}$ \\
\hline Number of rooms & 5.2 & 5.5 & $<0.01^{\mathrm{a}}$ & 5.2 & 5.3 & $0.29^{\mathrm{a}}$ \\
\hline Number of bathrooms & 0.8 & 0.9 & $<0.01^{\mathrm{a}}$ & 0.9 & 1.0 & $0.09^{\mathrm{a}}$ \\
\hline$\%$ of households with garbage collection & 59.5 & 70.4 & $0.01^{b}$ & 70.4 & 84.0 & $<0.01^{\mathrm{b}}$ \\
\hline$\%$ of households on the electric grid & 95.5 & 96.7 & $0.10^{\mathbf{b}}$ & 97.6 & 98.9 & $0.44^{b}$ \\
\hline$\%$ of households with piped water & 31.7 & 30.8 & $0.40^{\mathrm{b}}$ & 95.7 & 97.1 & $0.11^{\mathrm{b}}$ \\
\hline$\%$ of households with sewerage connection & 11.7 & 19.1 & $<0.01^{b}$ & 49.5 & 58.5 & $<0.01^{\mathrm{b}}$ \\
\hline$\%$ of masonry households & 86.6 & 91.7 & $0.01^{b}$ & 95.2 & 96.7 & $0.44^{\mathbf{b}}$ \\
\hline$\%$ of urban households & 73.0 & 71.5 & $<0.12^{b}$ & 68.7 & 70.1 & $0.12^{b}$ \\
\hline
\end{tabular}

Source: Created by the present study using data from the 2008/2009 Pesquisa de Orçamento Familiar (POF, Family Budget Survey).

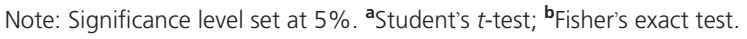


When the beneficiary families of the two regions are compared, those who live in the Northeast have worse homes and access to public services; for example, not even $12 \%$ of the beneficiary families in the Northeast had sewerage connection (Table 1).

The probit models that estimated the propensity scores returned the expected coefficients for most variables. In the Northeast region, variables that reduced the likelihood of being a PBF beneficiary were: higher per capita monthly income, higher education level of the household head, and higher number of bathrooms. On the other hand, households headed by women and those with more children and adolescents, or more sons and daughters were more likely to be beneficiaries (Table 2).

In the Southeast region, higher per capita monthly income, higher education level of the household head, and garbage collection reduced the likelihood of participation in the program. Meanwhile, households headed by women and those with a higher number of sons and daughters or children and adolescents increased the likelihood of participation (Table 2).
The total number of families used for estimating the effect (ATT) of the program on nutritional outcomes (underweight, stunting, and excess weight) was modified after the propensity score matching and exclusion of the matched family blocks (beneficiaries versus nonbeneficiaries) that did not satisfy the hypothesis of variable balancing. Thus, in the Northeast region, the number of families became 4,497 (1,858 beneficiaries), and in the Southeast, 972 (346 beneficiaries).

The nutritional status of children and adolescents aged 5 to 19 years before and after propensity score matching differed (Table 3 ).

Before score matching, the Northeast region had a smaller proportion of underweight and overweight/obese youth, and a higher proportion of stunting in beneficiary families as opposed to non-beneficiary families. In the Southeast region, the difference regarded the proportion of children and adolescents with excess weight, which was smaller in beneficiary families. After propensity score matching, the differences between the proportions of stunting

Table 2. Probit model of participation in the Bolsa Familia Program.

\begin{tabular}{|c|c|c|c|c|c|c|}
\hline \multirow{2}{*}{ Variables } & \multicolumn{3}{|c|}{ Northeast } & \multicolumn{3}{|c|}{ Southeast } \\
\hline & Coefficient & SE & $p$-value & Coefficient & SE & $p$-value \\
\hline Mean income per capita & -0.0512 & 0.0012 & $<0.01$ & -0.0421 & 0.0067 & $<0.01$ \\
\hline Household on the electric grid & 0.2157 & 0.1135 & 0.06 & -0.3569 & 0.8144 & 0.25 \\
\hline Masonry household & 0.0312 & 0.0741 & 0.82 & 0.0452 & 0.2993 & 0.98 \\
\hline Household with sewerage connection & -0.0988 & 0.0749 & 0.85 & 0.2144 & 0.1227 & 0.44 \\
\hline Household with garbage collection & -0.0611 & 0.0677 & 0.91 & -0.3157 & 0.1340 & 0.01 \\
\hline Number of bathrooms & -0.1729 & 0.0592 & $<0.01$ & -0.1688 & 0.1774 & 0.52 \\
\hline Number of household dwellers & 0.1364 & 0.0205 & 0.02 & -0.8571 & 0.0604 & 0.15 \\
\hline Number of children and adolescents & 0.4495 & 0.1603 & $<0.01$ & 0.7873 & 0.4295 & $<0.01$ \\
\hline Number of sons and daughters & 0.1966 & 0.0230 & 0.01 & 0.1596 & 0.0637 & 0.02 \\
\hline Urban household & 0.0471 & 0.6631 & 0.47 & 0.1587 & 0.1250 & 0.20 \\
\hline Female household head & 0.0931 & 0.0456 & 0.04 & 0.2101 & 0.0872 & 0.01 \\
\hline Brown skin color & 0.0742 & 0.0462 & 0.87 & 0.0330 & 0.0935 & 0.45 \\
\hline Education level of household head & -0.0205 & 0.0644 & $<0.01$ & -0.0282 & 0.0134 & $<0.01$ \\
\hline
\end{tabular}

Source: Created by the present study using data from the 2008/2009 Pesquisa de Orçamento Familiar (POF, Family Budget Survey). Note: SE: Standard Error. 
Table 3. Proportion of underweight, overweight/obese, normal weight, stunted, and non-stunted children and adolescents from families that benefit from the Bolsa Familia Program.

\begin{tabular}{|c|c|c|c|c|c|c|}
\hline \multirow{3}{*}{ Nutritional status } & \multicolumn{6}{|c|}{ Number of children and adolescents (\%) } \\
\hline & \multicolumn{3}{|c|}{ Before the matching } & \multicolumn{3}{|c|}{ After the matching } \\
\hline & Beneficiaries & Non-beneficiaries & $p$ & Beneficiaries & Non- beneficiaries & $p$ \\
\hline \multicolumn{7}{|l|}{ Northeast } \\
\hline Underweight & 4.05 & 4.60 & 0.03 & 4.15 & 5.32 & 0.01 \\
\hline Normal weight & 77.80 & 74.85 & 0.01 & 77.43 & 75.46 & 0.03 \\
\hline Excess weight & 18.15 & 20.55 & $<0.01$ & 18.42 & 19.22 & 0.16 \\
\hline Stunted & 7.80 & 6.08 & 0.02 & 8.11 & 7.85 & 0.11 \\
\hline Proper height & 92.20 & 93.92 & 0.03 & 91.89 & 92.15 & 0.08 \\
\hline \multicolumn{7}{|l|}{ Southeast } \\
\hline Underweight & 4.15 & 4.25 & 0.25 & 4.58 & 5.32 & 0.56 \\
\hline Normal weight & 72.50 & 70.67 & 0.31 & 72.78 & 68.41 & 0.22 \\
\hline Excess weight & 23.35 & 25.08 & 0.02 & 22.64 & 26.27 & 0.01 \\
\hline Stunted & 6.89 & 6.95 & 0.48 & 6.64 & 6.66 & 0.95 \\
\hline Non-stunted & 93.11 & 93.05 & 0.22 & 93.36 & 93.34 & 0.89 \\
\hline
\end{tabular}

Source: Created by the present study using data from the 2008/2009 Pesquisa de Orçamento Familiar (POF, Family Budget Survey). Note: Propensity score matching. Fisher's exact test with a significance level of $5 \%$.

Table 4. Average effect of treatment on the proportion of underweight, overweight/obese, normal weight, stunted, and non-stunted children and adolescents.

\begin{tabular}{|c|c|c|c|c|c|c|}
\hline \multirow{2}{*}{ Nutritional status } & \multicolumn{3}{|c|}{ Northeast } & \multicolumn{3}{|c|}{ Southeast } \\
\hline & ATT & SE & $t$ & ATT & SE & $t$ \\
\hline Underweight & -0.011 & 0.009 & $-2.122^{*}$ & -0.020 & 0.012 & -1.075 \\
\hline Normal weight & 0.007 & 0.001 & 0.898 & 0.009 & 0.003 & 1.002 \\
\hline Excess weight & -0.015 & 0.015 & -0.933 & -0.042 & 0.036 & $-1.980^{*}$ \\
\hline Stunted & 0.014 & 0.012 & 1.015 & 0.007 & 0.019 & 0.386 \\
\hline Non-stunted & -0.004 & 0.001 & -1.106 & 0.005 & 0.002 & 1.101 \\
\hline
\end{tabular}

Source: Created by the present study using data from the 2008/2009 Pesquisa de Orçamento Familiar (POF, Family Budget Survey). Note: ATT values expressed in terms of proportion. $t$ statistic: *Indicates significance at the $5 \%$ level.

ATT: Average effect of Treatment on the Treated; SE: Standard Error.

and excess weight in beneficiary and nonbeneficiary Northeast families ceased to exist (Table 3).

The estimated impact of the program (ATT) on the study nutritional outcomes indicated that in the Northeast region, the proportion of underweight children and adolescents in the beneficiary families was, on average, 1.1\% smaller than that in the non-beneficiary families. In the Southeast region, the proportion of overweight/obese children and adolescents was, on average, $4.2 \%$ smaller in beneficiary families (Table 4).

\section{DISCUSSION}

The results indicated that the PBF had a positive impact on the nutritional status of children and adolescents aged 5 to 19 years in both study regions. In the Northeast the beneficiary families had a smaller proportion of underweight children and adolescents, and in 
the Southeast, they had a smaller proportion of overweight/obese children and adolescents. These results, especially those that regard the Northeast, rectify the appropriate focus of the program as this region concentrates the country's highest prevalence of food insecurity [10]. Families that live in food insecurity may have difficulties to access adequate and healthy food, which may contribute to unfavorable nutritional diagnoses, such as malnutrition, for example.

Assessment of public policies provides scientific evidence for political decision making. However, impact assessment studies must use the appropriate methodology, especially regarding sampling and confounder control. The present study used propensity score matching to match the families and estimate the impact of the PBF. This technique is recommended for assessing the impact of social policies and produces robust and reliable results [13].

The importance of using this technique was evidenced as the difference in the proportions of stunted and overweight/obese children and adolescents from the Northeast lost significance after matching. Propensity score matching makes the intervention and control groups more similar and homogeneous, allowing one to identify the effect of the program on the study nutritional outcomes, controlling possible confounders.

The prevalence of underweight in children and adolescents from the Northeast is one of the highest in the country, while excess weight is more prevalent in the Southeast [1]. Hence, the PBF had a positive impact on nutritional outcomes, which stem from the social, economic, and cultural differences between these two regions [14]. The Southeast region is more exposed to unhealthy food chains, such as fast food chains. Moreover, this region has a higher proportion of youth who eat away-fromhome than the rest of the country. This context facilitates less healthy food choices that may contribute to weight gain [15].
Studies that assessed the impact of the PBF on children's nutritional status have also found positive results [16-18]. In a populationbased study, beneficiary children were $26 \%$ more likely to have proper weight- and height-forage than non-beneficiaries, that is, participation in the program was among the factors that protected children from malnutrition [16].

Malnutrition is associated with delayed psychomotor development, lower school performance, and higher vulnerability to infectious diseases, which may increase mortality $[2,19]$. Brazil has advanced in the development of an agenda to fight hunger and malnutrition, which allowed it to achieve early the goal to reduce childhood malnutrition set by the first Millennium Development Goals [20].

Among the main determinants of this achievement are higher maternal education level, family income, and access to primary health care $[2,20]$. The cash transfer programs made an important contribution to the increase in family income, especially the $\operatorname{PBF}[5,7]$. In addition to increasing purchasing power, studies reinforce that the money is primarily spent on food acquisition, which may help to reduce food insecurity [21-23].

Therefore, as reported by some studies, the Brazilian decision to link cash transfer to compliance with some health requirements, especially those related to nutritional monitoring, have resulted in positive impacts on malnutrition and excess weight [12-14], and reduced poverty and social inequality $[4,5,7]$, which actually are the expected consequences of a cash transfer program.

In the present study, the program did not impact the indicator height-for-age in either region. The proportions of stunted children and adolescents were high both in beneficiary and non-beneficiary families.

Stunting is an important indicator of quality of life [24]. As the study beneficiary and non-beneficiary families had similar sets of socioeconomic variables and these indicated 
situations of multiple vulnerabilities, we reinforce the importance of adopting more structural actions, such as investments in health, education, work, and basic sanitation, which should occur in parallel with cash transfer programs to reduce stunting.

Brazil is currently undergoing nutrition transition due to changes in lifestyle and eating habits. Higher intake of ultra-processed foods, which contain high energy density and simple sugar, sodium, and saturated fat contents, are related to a higher prevalence of excess weight. The intake of these foods is greater in economically more developed regions, like the Southeast $[25,26]$.

The proportion of overweight/obese children and adolescents from the Southeast region in beneficiary families, although high, was smaller than that in non-beneficiary families. These results demand attention as temporal trend analysis of nutritional status and food intake in Brazil show a growing prevalence of excess weight and intake of ultra-processed foods in all income strata $[26,27]$. Therefore, beneficiary families should be encouraged to use the complementary income to acquire healthy foods, especially in the Southeast, as lifestyle and ease of access make people more likely to consume unhealthy foods, which can increase the prevalence of excess weight in this region.

Inserting the theme Food and Nutrition Education (FNE) in the scope of the ongoing actions as a health requirement for receiving the benefit would be a way to stimulate healthy autonomous food choices, which have a positive impact on the nutritional status of children and adolescents who are in the process of forming food habits and who are vulnerable to nutritional deficiencies $[28,29]$. Nevertheless, the adoption of a healthy diet is not merely an individual issue. FNE actions are essential for the promotion of healthy food habits as long as they are coordinated with structural strategies ranging from food production to consumption, which requires the implementation of intersectoral public policies.
From 2011, the Plano Brasil sem Miséria (Brazil without Poverty) promoted important changes in the PBF, such as increasing the national coverage of the program, the number of beneficiaries, and the amount of cash transferred [6]. Thus, we reinforce the importance of conducting a study comparative to this one (using data from the next POF) to assess the temporal trend of the nutritional indicators of PBF beneficiaries and whether the changes that are in the design of the program, such as those mentioned earlier, have a positive effect on the beneficiaries' health and nutrition.

\section{FINAL CONSIDERATIONS}

The impacts of the PBF on the nutritional status of children and adolescents aged 5 to 19 years determined herein show proper focus and results beyond expectation for a cash transfer program, which would be to reduce poverty and social inequality.

The Brazilian decision to transfer cash on the condition of compliance with a list of health and education requirements has contributed to improve the life and health conditions of PBF beneficiaries. However, it is still necessary to provide quality health and education services, insert the theme of food and nutrition education in the health requirements, and adopt structuring measures, such as housing and basic sanitation improvement, especially in the Northeast to maximize the impacts of the program on quality of life and to break the intergenerational poverty cycle.

\section{CONTRIBUTORS}

N SPERANDIO conceived and designed the study, wrote and reviewed the intellectual content, and approved the final version of the manuscript. CT RODRIGUES analyzed and interpreted the results and approved the final version of the manuscript. SCC FRANCESCHINI and SE PRIORE reviewed the content and approved the final version of the manuscript. 


\section{REFERE N CES}

1. Instituto Brasileiro de Geografia e Estatística. Pesquisa de Orçamento Familiar (POF) - 2008-2009: antropometria e estado nutricional de crianças, adolescentes e adultos no Brasil. Rio de Janeiro: IBGE; 2010.

2. Monteiro CA, Benicio MHA, Konno SC, Silva ACF, Lima ALL, Conde WL. Causes for the decline in child under-nutrition in Brazil, 1996-2007. Rev Saúde Pública. 2009;43(1):35-43.

3. Batista FM, Rissin A. Nutritional transition in Brazil: Geographic and temporal trends. Cad Saúde Pública. 2003;19(Suppl.1):S181-S91.

4. Rasella D, Aquino R, Santos CA, Paes-Souza R, Barreto ML. Effect of a conditional cash transfer programme on childhood mortality: A nationwide analysis of Brazilian municipalities. Lancet. 2013;382(9886):57-64.

5. Martins AP, Canella DS, Baraldi LG, Monteiro CA. Cash transfer in Brazil and nutritional outcomes: A systematic review. Rev Saúde Pública. 2013;47(6):1159-71.

6. Ministério do Desenvolvimento Social e Combate à Fome (Brasil). Bolsa Família. Brasília: Ministério do Desenvolvimento Social e Combate à Fome; 2016 [acesso 2016 jan 10]. Disponível em: http:// www.mds.gov.br/bolsafamilia/beneficios

7. Cotta R, Machado JC. The Bolsa Família cash transfer program and food and nutrition security in Brazil: A critical review of the literature. Rev Panam Salud Publica. 2013;33(1):54-60.

8. Instituto Brasileiro de Geografia e Estatística. Pesquisa sobre padrões de vida 1996-1997. $2^{a}$ ed. Rio de Janeiro: IBGE; 1999.

9. Abrantes MM, Lamounier JA, Colosimo EA. Prevalência de sobrepeso e obesidade em crianças e adolescentes das regiões Sudeste e Nordeste. J Pediatr. 2002;78(4):335-40.

10. Instituto Brasileiro de Geografia e Estatística. Pesquisa nacional de amostra por domicílios. Rio de Janeiro: IBGE; 2013.

11. World Health Organization. Physical status: The use and interpretation of anthropometry. Report of a WHO Expert Committee. Geneva: WHO; 1995.

12. Onis $M$, Onyango AW, Borghi $E$, Siyam $A$, Nishida C, Siekmann J. Development of a WHO growth reference for school-aged children and adolescents. Bull World Health Organ. 2007;85(9):660-7.
13. Khandker SR, Koolwal GB, Samad HA. Handbook on impact evaluation quantitative methods and practices. Washington (DC): The World Bank; 2010.

14. Travassos C, Viacava F, Fernandes C, Almeida CM. Desigualdades geográficas e sociais na utilização de serviços de saúde no Brasil. Ciênc Saúde Coletiva. 2000;5(1):133-49.

15. Bezerra IN, Souza AM, Pereira RA, Sichieri R. Consumo de alimentos fora do domicílio no Brasil. Rev Saúde Pública. 2013;47(Suppl.1):200s-11s.

16. Paes-souza R, Santos LMP, Miazaki ES. Effects of a conditional cash transfer programme on child nutrition in Brazil. Bull World Health Organ. 2011;89(7):496-503.

17. Camelo RS, Tavares PA, Saiani CCS. Alimentação, nutrição e saúde em programas de transferência de renda: evidências para o Programa Bolsa Família. Rev Econom Selecta. 2009;10(18):685-713.

18. Piperata BA, Spence JE, Da-Gloria P, Hubbe M. The nutrition transition in Amazonia: Rapid economic change and its impacto $n$ growth and development in Ribeirinhos. Am J Phys Anthropol. 2011;146(1):1-13.

19. Conde CMG. Desnutrição: um desafio secular à nutrição infantil. J Pediatr. 2000;76(Supl.3):S285-S97.

20. Instituto de Pesquisa Econômica Aplicada. Objetivos de desenvolvimento do milênio: relatório nacional de acompanhamento. Brasília: Instituto de Pesquisa Econômica Aplicada; 2014.

21. Duarte GB, Sampaio B, Sampaio Y. Programa Bolsa Família: impacto das transferências sobre os gastos com alimentos das famílias rurais. Rev Econ Sociol. 2009;47(4):903-18.

22. Lignani JB, Sichieri R, Burlandy L. Changes in food consumption among the Programa Bolsa Família partipant families in Brazil. Public Health Nutr. 2010;14(5):785-92.

23. Piperata BA, Ivanova SA, Glória P, Veiga G, Polsky $A$, Spence JE, et al. Nutrition in trasition: Dietary patterns of rural Amazonian woman during a period economic change. Am J Human Biol. 2011;23(4):458-69.

24. Oliveira FCC, Cotta RMM, Sant'Ana LFR, Priore SE, Franceschini SCC. Programa Bolsa Família e estado nutricional infantil: desafios estratégicos. Ciênc Saúde Coletiva. 2011;16(7):3307-16.

25. Instituto Brasileiro de Geografia e Estatística. Pesquisa de Orçamento Familiar (POF) - 2008-2009: análise do consumo alimentar pessoal no Brasil. Rio de Janeiro: IBGE; 2011. 
26. Levy-Costa RB, Sichieri R, Pontes NS, Monteiro CA. Disponibilidade domiciliar de alimentos no Brasil: distribuição e evolução (1973-2003). Rev Saúde Pública. 2005;39(4):530-40.

27. Martins APB, Levy RB, Claro RM, Moubarac JC, Monteiro CA. Participação crescente de produtos ultraprocessados na dieta brasileira (1987-2009). Rev Saúde Pública. 2013;47(4):656-65.

28. Lima FEL, Fisberg RM, Uchimura KY, Picheth T. Programa Bolsa Família: qualidade da dieta de população adulta do município de Curitiba, PR. Rev Bras Epidemiol. 2013;16(1):58-67.

29. Sidaner E, Balaban D, Burlandy L. The Brazilian school feeding programme: An example of an integrated programme in support of food and nutrition security. Public Health Nutr. 2013;16(6):989-94.

Received: January 2, 2016

Final version: July 7, 2016

Approved: September 22, 2016 
